UDC: 332.2

\title{
DEVELOPMENT OF ECOLOGICAL AND ECONOMIC MEASURES FOR CREATING OF THE SUSTAINABLE LAND USE
}

\author{
Hetmanchyk I., Candidate of Economics., Associate Professor \\ Kolhanova I., Getter \\ National University of Life and Environmental Sciences of Ukraine \\ E-mail: kolganova_i@ukr.net
}

The article deals with ecological and economic measures for creating of the sustainable land use, it's current state and problems as well as areas of improvement.

These measures directed to ensure balanced of needs of the population and economic sectors by land resources, rational use and protection of lands, preservation

of landscape and biological diversity, creation of environmentally safe living conditions

of the population and economic activity and protection of lands from depletion, degradation and pollution.

Key words: sustainable land use, lands of nature conservation and natural reserve purpose, ecological network, agrolandscape.

\section{Formulation of the problem.}

Human activities and related factors led to loss and considerable fragmentation of natural areas. Landscape complex of most part of the territory of Ukraine can be called natural - conditionally: almost on $60 \%$ of the area formed changed anthropogenically-natural landscapes. Nominally unchanged remained only landscape complexes - forest $(16 \%)$ and reserve fund $(3,7$ $\%$ ). The rest make up the urban areas (to $7 \%$ ) with almost radically changed natural complexes, and also squally complexes (4\%) and others (swamps, ravines, floodplain, sands, broken lands). If in the mountain systems of the Ukrainian Carpathians and Crimea, in forests of the Ukraine has remained fairly rich diversity, then over-exploita- tion of steppe lands (plough up of lands in the steppe zone exceeds $80 \%$, the average for Ukraine 54,6\%) has led to almost complete destruction of natural areas there. This poses a threat to the loss of ecological stability of territory. In Ukraine, almost $70 \%$ of territory occupied by agricultural lands, including tillage - almost $54,6 \%$, whereas still by researches of Dokuchaieva were established, that proportion of tillage should not exceed $35-40 \%$. These indicators are among the highest in the world, and therefore logical to assume, that agriculture in our country has a particularly significant impact on biological diversity [1].

Agricultural impact on biodiversity manifested in destruction of natural vegetation during plowing up of new territories, soil degradation, drainage 
of wetlands, deforestation for creating of the fields, environmental pollution by pesticides and fertilizers. Agriculture and biodiversity are closely linked. Without services which providing by biodiversity to agriculture, many of it's branches would lose their productivity.

\section{Analysis of recent scientific researches and publications.}

In Ukraine, the study of this problem involved a significant number of scientists. First of all this research of scholars such as: L.Ia. Novakovskyi, D.S. Dobriak, I.A. Rozumnyi, A.H. Tykhonov, A.M. Tretiak, A.Ia. Sokhnych, O.P. Kanash, A.D Yurchenko, V.O. Leonets, S.O. Osypchuk and others. However, a number of issues still remain insufficiently explained and needs further processing.

The purpose of the article. The essence of agricultural land use, it's problems and directions of improvement. Development of ecological and economic measures for creation of the sustainable land use.

\section{Statement of main material.}

Despite the fact that the environmental component of the agricultural policy in Ukraine not so clearly expressed as in agricultural policy of the European Union and many other countries, Ukrainian government also made some steps to solve environmental problems, that arising as a result of agricultural activities. One such step is the development of «Concepts of balanced (sustainable) development of agro-ecosystems in Ukraine on period till 2025», which was approved in 2003. Main directions of activity in sphere of creating of conditions for sustainable development of agro-ecosystems in Ukraine includes: gradual establishment of ecological balance ratio of lands in zonal systems of land use, by which is supported the homeostasis of the biosphere; reduction of area of arable lands to 35-40\% of territory of the country by removing from tillage slopes precipitous over $3^{\circ}$, lands of water protection zones, degraded, low productivity and technologically contaminated agricultural lands; increasing of the environmental and stabilizing lands; the creation of new areas and expanding of existing areas and objects of natural reserve fund within the limits of agricultural lands; creating the conditions for ensuring the continuity of natural areas of ecological niches within the limits of agricultural lands; develop an ecological network as part of European and formation of it's constituent parts; ensuring wide implementation of new ecologically balanced technologies in agriculture and supporting of development of the biological agriculture; extension of the order and the introduction of economic incentives of landowners and land users concerning of conducting of ecologically balanced agricultural activities; development of indicators of biodiversity of the plant world in connection with the conducting of agricultural activities; development of biodiversity indicators of wildlife in connection with the conducting of agricultural activity.

These directions, which are considered through the implementation of complex of organizational, legal, ecological and economic and other measures, will allow to suspend the processes of soil degradation, minimize of erosion processes, create a stable system increasing of resource potential of lands and improve the economic efficiency of their use [5]. 


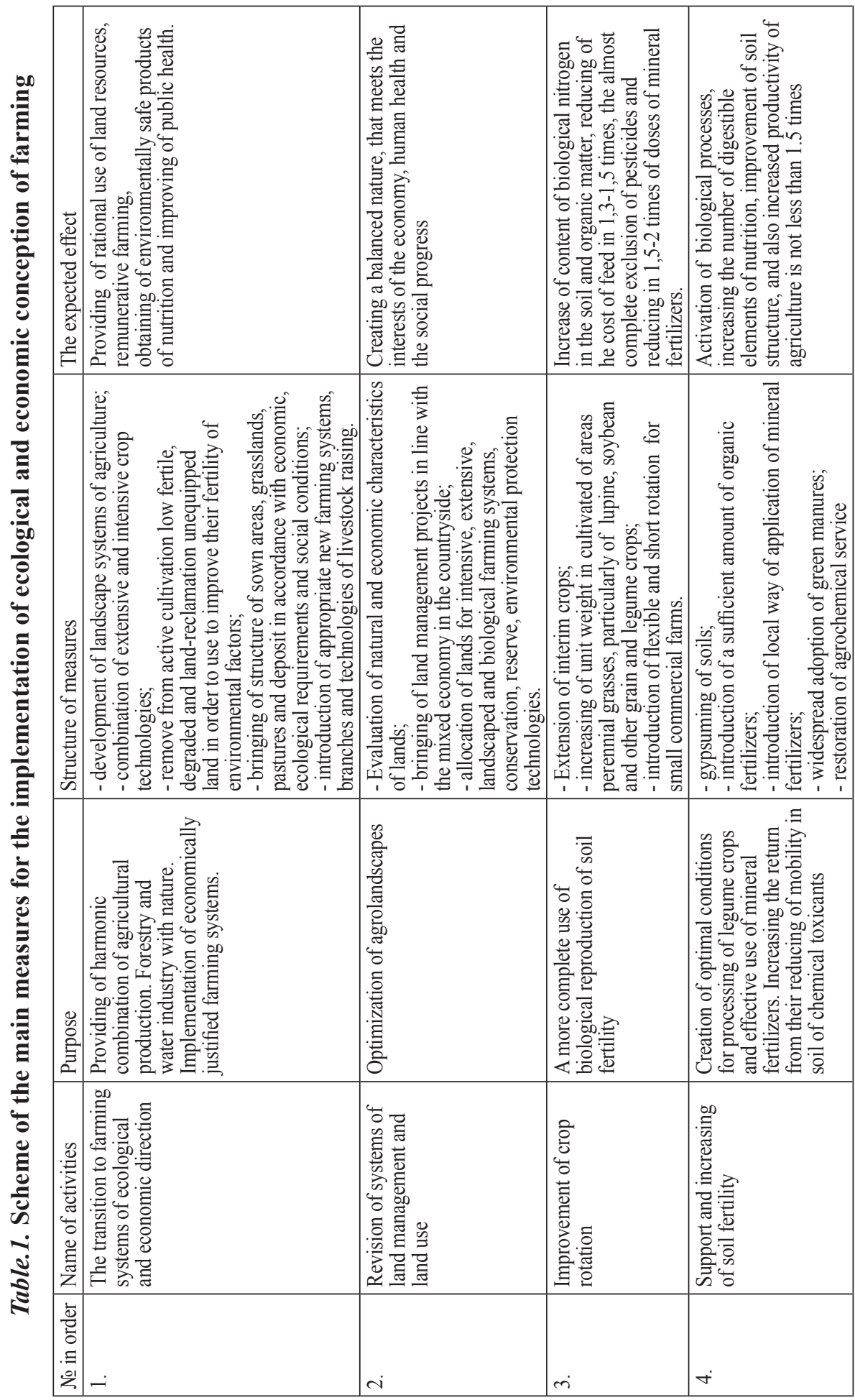




\begin{tabular}{|c|c|c|c|}
\hline 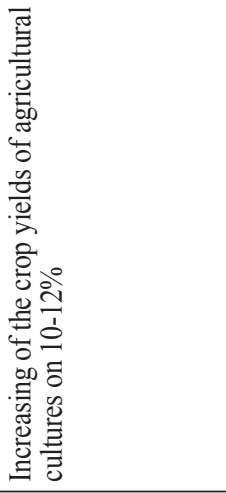 & 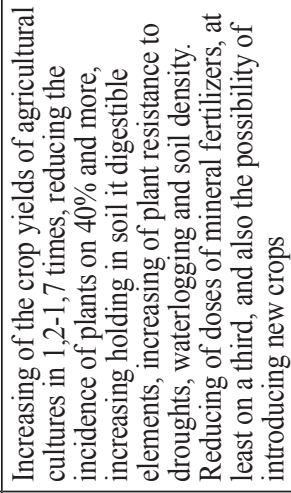 & 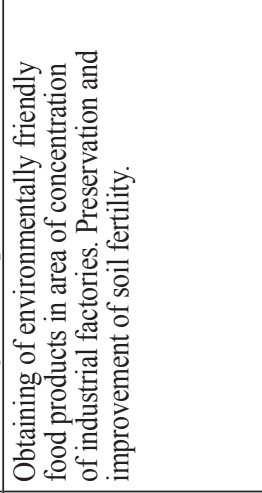 & 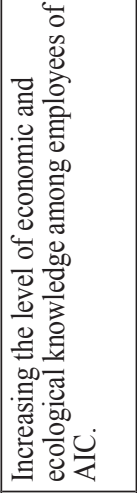 \\
\hline 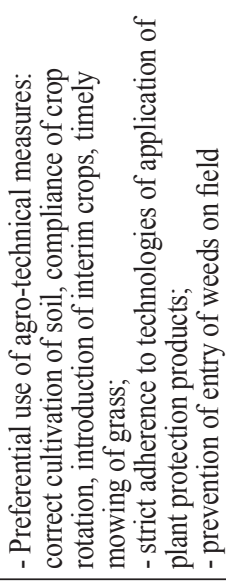 & 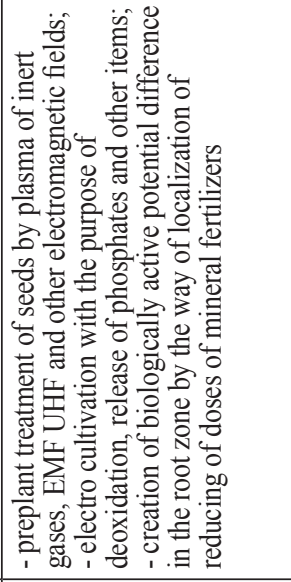 & 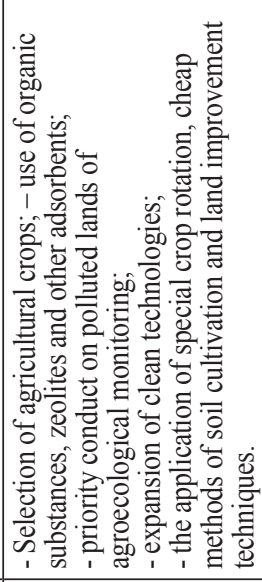 & 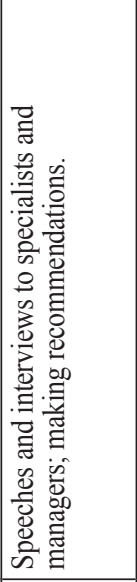 \\
\hline 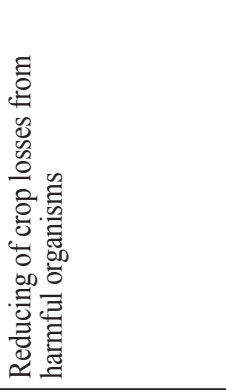 & 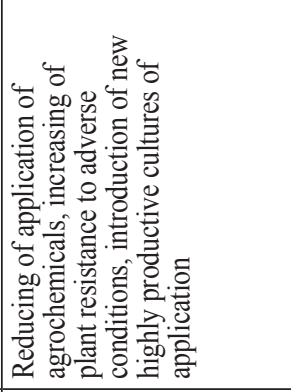 & 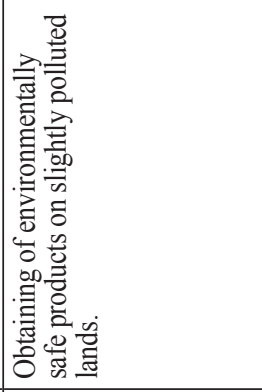 & 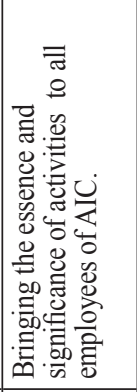 \\
\hline 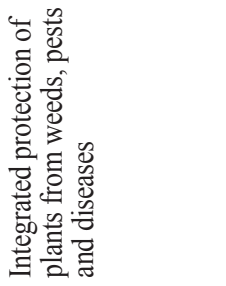 & 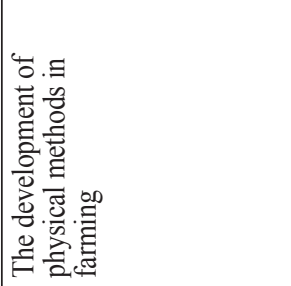 & 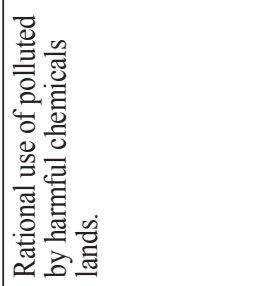 & 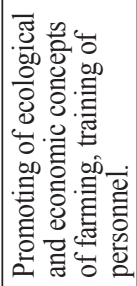 \\
\hline in & $0^{\circ}$ & $\therefore$ & $\infty$ \\
\hline
\end{tabular}


In The Land Code of Ukraine [3] land declared as a national treasure and provides the ensure of the rational use and protection of lands. Land Code from among other categories of land alone identifies land of nature conservation and natural reserve designation, which includes natural areas and objects, artificially created objects, and also lands of other nature conservation importance, which include land plots of wetlands, which is not attributed to lands of water fund and lands of forestry purpose and land plots, within which are natural objects, which have a special scientific value.

One of the most important steps in the conservation of diversity in Ukraine was the beginning of the creation of the ecological network. Ecological network is a system of protected territories, ecological corridors, which allowing to wild species of animals and birds move between the protected cores, buffer zones and other spatial elements, which which form a net of which form a net of favorable for wild species of habitats [4].

Along with the reserves and other ecologically valuable natural objects with the strict limitation of human activity, the law provides for the inclusion in the ecological network such objects of agricultural landscapes, as fields shelter belts and other protective plantings, lands of water fund, wetlands, water protection zones, steppe vegetation areas, stone placers, sands, salt marshes and partly agricultural lands of extensive using - pastures, hayfields, etc.. [2].

Transformation of land relations and land use systems during the years of land reform has led to the largest decline of agricultural production. Decreased areas of grain and forage crops (especially perennial grasses). All this of course could not affect the quality state of biodiversity, especially in agricultural enterprises and farms, land use of which stands out the lack of crop rotation, providing preference to growing profitable crops (corn to the grain, winter wheat, soy, rape, sunflower) without taking into account of soil ecology. In addition, reducing of application of organic fertilizers leads to reduced of soil fertility and depletion of microflora. So as a result - unstable land use and considerable human pressure on agricultural landscapes, as well as reducing biocenotical and other environmental measures concerning the organization of ecologically land use.

Providing of environmental and economic security of agricultural land use is determined by such indicators of ecological compatibility as: number of land resources that are using and their ratio; efficiency (intensity) of using of land resources; level of fertilizer application, herbicides or waste disposal; the amount of emissions or violations, which influenced the environment; the number of outstanding of land protection and land management measures; quantity of gaseous harmful substances that released into the environment; investment in the environmental protection; the number and value of environmental penal sanctions; sum of payments for wastewater discharges; other costs which connected with environmental using.

Ecological and landscape approach involves establishing of the optimum ratio of area of arable lands, pastures, hayings, preserves, forest plantations, settlemens and other anthropogenic environments stabilizing components, which contribute to self-regulation of agricultural landscapes. The optimal ratio of these lands is the better, how it is closer to the natural (natural) landscape. It is known that the stabilizing 
function of the landscape is enhanced by the farming system and its main link - crop rotations, which are being developed on the terrain in land management projects. For the majority of agricultural lands, which are owned by citizens and legal entities, environmental protection restrictions regarding their use can be established only through the implementation of land management projects.

To the ecological and economic conception of reffering such issues: improvement of land management and land use, crop rotation system; processing of soil, application of fertilizers and other parts of farming systems taking into account the of organizational and economic and social conditions, that changing and widespread use of physical factors of increase yields.

We have concrete measures, needed for practical implementation of environmental and economic conception of agriculture in the current circumstances. Look. Table 1.

\section{Conclusion.}

Agricultural and anthropogenic influence is one of the most dangerous. Rational use of land resources in the steppe landscapes and the creation of sustainable land use is not possible without complex of measures for creating ecological and economic conception of farming. We need ecological imperative in land use - changing of the system of values, which guiding in land legislation, economy and everyday life. Measures that being considered in the article should be integral part of the activities to ensure of ecological balance, social stability, national security, and will contribute to the promotion of Ukraine into the European community as a stateThat fulfills its international legal obligations in the field of environmental protection.

Formation of economically efficient and socially and environmentally balanced system of land use and nature management in Ukraine is a dynamic processWhich should be regulated in the public interests. On the optimization of land use та and nature management should be directed political, organizational and legal, social and economic and ecological management government actions. Thus the priority importance attaches to the public interests in achieving of high economic efficiency of land use on condition of environmental sustainability of natural resources. Thus, the modern transformation of land use in any areas of social development should obtain environmental vector.

\section{References}

1. (2005) Ahrobioriznomanittia Ukrainy: teoriia, metodolohiia, indykatory, pryklady. [Agrobiodiversity of Ukraine: Theory, Methodology, Indicators, Examples.] Kyiv: ZAT «Nichlava», 384.

2. Budziak O.S. (2015) Ekolohichna merezha Ukrainy v konteksti formuvannia pryrodookhoronnoho zemlekorystuvannia: stan ta problemy [Environmental network Ukraine in the context of formation of nature conservation of land use: situation and problems]. MVTs «Medinform», 113.

3. Land Code of Ukraine. Available at:http:// zakon4.rada.gov.ua/laws/show/2768-14.

4. Nesterov lu. V. (2005). Praktychni porady zi zberezhennia bioriznomanittia u silskohospodarskykh uhiddiakh. [Reccomendations to the conservation of biodiversity in farmlands]. Wetlands International Black Sea Programme, 48.

5. Osypchuk S.O. (2006). Kontseptualni polozhennia suchasnoi stratehii vykorystannia zemelnykh resursiv Ukrainy [Conceptual provisions of the modern strategy of using 
of land resources]. Scientific Bulletin of National Agricultural University, 104, $71-78$.

6. Semenova V.F., Mykhailyk O.L. (2004). Ekolohichnyi menedzhment: Navchalnyi posibnyk [Environmental Management: Textbook]. Kyiv, Ukraine: Center of educational literature, 407.

\section{$* * *$}

Гетманьчик І.П, Колганова І.Г РОЗРОБКА ЕКОЛОГО-ЕКОНОМІЧНИХ ЗАХОДІВ ЩОДО ФОРМУВАННЯ СТАЛОГО ЗЕМЛЕКОРИСТУВАННЯ

Висвітлено еколого-економічні заходи щодо формування сталого землекористування, його сучасний стан і проблеми, а також напрями вдосконалення. Ці заходи направленні на збалансоване забезпечення потреб населення і галузей економіки земельними ресурсами, раціональне використання та охорону земель, збереження ландшартного та біологічного різноманіття, створення екологічно безпечних умов проживання населення й господарської діяльності та захист земель від виснаження, деградації і забруднення.

Ключові слова: стале землекористування, землі природоохоронного та при- родно-заповідного призначення,екологічна мережа, агроландшарт.

\section{*** \\ Гетманьчик И.П., Колганова И.Г РАЗРАБОТКА ЭКОЛОГО-ЭКОНОМИ- ЧЕСКИХ МЕРОПРИЯТИЙ ПО ФОРМИРО- ВАНИЮ УСТОЙЧИВОГО ЗЕМЛЕПОЛЬЗО- \\ ВАНИЯ}

Освещены эколого-экономические мероприятия по формированию устойчивого землепользования, его современное состояние и проблемы, а также направления совершенствования. Эти меры направлены на сбалансированное обеспечение потребностей населения и отраслей экономики земельными ресурсами, рациональное использование и охрану земель, сохранения ландшафтного и биологического разнообразия, создание экологически безопасных условий проживания населения и хозяйственной деятельности и защиту земель от истощения, деградации и загрязнения.

Ключевые слова: устойчивое землепользование, земли природоохранного и природно-заповедного назначения, экологическая сеть, агроландшафт. 